\title{
Job Dissatisfaction and Turnover Crises in Tunisia
}

\author{
Hanen Khanchel ${ }^{1} \&$ Karim Ben Kahla ${ }^{2}$ \\ ${ }^{1}$ Institute of Advanced Business Studies, Carthage, Tunisia \\ ${ }^{2}$ High Business School, Campus of Manouba \\ Correspondence: Hanen Khanchel, Institute of Advanced Business Studies, Carthage, Tunisia. E-mail: \\ Hanen.Khanchel@gmail.com
}

Received: July 12, 2019

Accepted: August 13, 2019

Online Published: September 26, 2019

doi:10.5430/bmr.v8n3p53

URL: https://doi.org/10.5430/bmr.v8n3p53

\begin{abstract}
The purpose of this paper is to develop a scale to measure employee satisfaction and test the nature of the relationship between job dissatisfaction and turnover; and to test if some sociodemographic variables can moderate this relation same as above. Data was collected from Tunisian Information and Communications Technology Sector (ICT). As quantitative methodology employs numerical data to quantify the social phenomenon, choosing the right techniques enable social scientists to analyse the findings of the study accurately using both structural equation analysis and hierarchical regression. The results indicated that the level of employee dissatisfaction influences their turnover intention. The results confirm that job dissatisfaction has an even greater impact on departure intentions as the level of satisfaction is low. A Likert scale is developped in this study, often found on survey forms, that measures how people feel about Quality of Working life.
\end{abstract}

Keywords: job, dissatisfaction, turnover, crises, Tunisia

\section{Introduction}

The relationship between employee dissatisfaction and departure intentions or turnover has been the subject of several studies (Murrar et Hamad, 2013; Clark, 2001, Mohsina et al, 2013; Lambert and al, 2001; Jang and George, 2012; Yucel and Bektas, 2012; Muchinsky and Tuttle, 1979). The aggregate results show that certain dimensions of employee satisfaction are the main determinants of employee mobility (Alfonso Sousa-Poza, Andres A. Sousa-Poza, 2007). The underlying argument is that satisfied employees are inclined to focus on their business and significantly reduce their original intentions and vice versa (Chan Yin-Fah et al, 2010, Adams, 1963, Withey and Cooper). 1989 cited by Arndt et al, 2006).

The distinction made between job satisfaction and dissatisfaction in Quality of Working life reflects the influence of job satisfaction theories. Herzberg et al., (1959) used "Hygiene factors" and "Motivator factors" to distinguish between the separate causes of job satisfaction and job dissatisfaction. It has been suggested that Motivator factors are intrinsic to the job, that is; job content, the work itself, responsibility and advancement. The Hygiene factors or dissatisfaction-avoidance factors include aspects of the job environment such as interpersonal relationships, salary, working conditions and security. Of these latter, the most common cause of job dissatisfaction can be company policy and administration, whilst achievement can be the source of satisfaction.

This study focuses on employee dissatisfaction and its relationship with intentions to leave or change jobs. This choice is dictated by the importance of these employees (Heskett et al, 1994, Hoffman and Ingram, 1992, Schneider and Bowen, 1993 cited by Bettencourt and Brown, 1997, Burmann and Konig, 2011, Fang et al, 2011 cited by Malhotra et al, 2013).

Very few surveys have been devoted to study Employee Dissatisfaction and Turnover Crises (Canales 2010, Dixon et al 2007, Abbing 2011, Uchida et al 2012). Those that exist relate to (a) the difficulties that employees experience in carrying out their work (Dixon et al, 2007, Abbing, 2011), (b) the possibility of employees discriminating against certain potential activities depending on the strategic position they occupy in the company's business process (Labie et al, 2009, Beck et al, 2011) and on (c) the issue of compensation and benefits granted to agents (McKim et al. Hughart 2005, Aubert et al 2009, Armandariz and Morduch 2005, among others). Studies that directly analyze employee satisfaction beyond the compensation and benefits of employees and its links to turnover intentions are, to our knowledge, non-existent in the ICT field. This study therefore wants to fill this gap. 
The purpose of this study is: (a) to develop a scale previously measure employee dissatisfaction and test the nature of the relationship between employee satisfaction and turnover; and (b) check whether socio-demographic variables are variables that can moderate or amplify this relationship (Mohsin Bashir et al, 2011, Yucel and Bektas, 2012). First, it addresses a topic that has been little or no analyzed in the literature (Mansor et al, 2012). This study aims to identify the dimensions of employee dissatisfaction that decision makers can use to retain the best employees (Ross and Denzer, 2011). Second, this study is conducted in a Tunisian context of crisis after the events of 14 January 2011. This context is characterized by a high unemployment rate (Sahnoun and Abdennadher, 2019) to such an extent that even dissatisfied employees would tend to stay within their company. Such behavior justifies the importance of analyzing the issue of turnover intentions rather than shift changes because employees would find it difficult to leave their establishment because of a lack of alternatives. Initiation intentions are analyzed according to whether they are directed towards other companies offering better job prospects or to other sectors in which employees hope to achieve their full potential. The data was collected from a sample of 100 employees. Data processing was obtained by successively using structural equations and hierarchical regression.

Indeed, this study is organized around four sections. The first section presents the theoretical model as well as the different hypotheses tested in this paper. The second section presents the methodology. The third section presents the results while the fourth section gives the main conclusions, the limits as well as the leads for future studies.

The purpose of this study is to develop a scale to measure employee satisfaction and test the nature of the relationship between job dissatisfaction and turnover; and to test if some sociodemographic variables can moderate this relation same as above. Data was collected from Tunisian Information and Communications Technology Sector (ICT).

\section{Theoretical Model and Hypothesis Development}

Employee dissatisfaction is one of the most studied concepts in human resource management, occupational psychology and marketing (Sepctor, 1997). This term goes back to the pioneering work of Hoppock (1935) which also offers the first definition: "job satisfaction is the combination of psychological, physical and environmental circumstances that lead a person to say," I am satisfied with my work ". Locke (1969) completes this definition by highlighting the evaluation process that characterizes employee satisfaction. Thus he defines, job satisfaction as "a positive emotional feeling resulting from the assessment that the individual makes of his work in international and those receiving subsidies and who can therefore pay substantial basic salaries. The list of employees who participated in this survey and which served as a basis for this study can be found in this paper.

By making a comparison between the benefits he was hoping to get and what he actually gets from it. «This definition was later taken up by Igalens (1999) cited by Moutte (2010) when he states that job satisfaction is "a positive emotional response resulting from the evaluation of work experiences".

Job dissatisfaction is often measured across multidimensional scales or not to provide an overview of variables that satisfy employees at work. The first scales were forged in the 1960s (USA). Among the most popular scales are: Job Satisfaction Survey, Job Descriptive Index, Minnesota Satisfaction Questionnaire, Job Diagnostic Survey, Job in General Scale and the Michigan Organizational Assessment Questionnaire Subscale (Spector, 1997). Although most of these scales were developed several years ago, they still serve as a basis for studies to assess employee satisfaction in several countries and industries.

The turnover intention is often defined as an internal individual force that pushes an employee to want to quit his current job and to actively seek others job opportunities that meet his expectations. It is therefore a continual trend of employees to resign themselves to their current job (Ching-Li Fan, 1978, Tzu-Chi Wang, 2000; Caplan and Jones, 1975). Mobley et al (1978) cited by Gao-Liang Wang et al (2012) define the turnover intention as "the aggregation of dissatisfaction work, the tendency to look for other jobs and the possibility of finding another job ". Moreover, Williams and Hazer (1986) cited by Gao-Liang Wang et al (2012) corroborate this definition. Concluding that the intent of departure is a plan that employees are forming about the willingness to leave their jobs. Ahmad et al (2012) confirm these facts when they say that "the intention to leave the organization relates to the desire to leave the organization of permanently ".

Lambert et al (2001) argue that there are three variables that are likely to explain intention to leave within a company: the demographic characteristics of the employees, job satisfaction and the work environment. The Theoretical Model (Muchinsky and Tuttle 1979, Spector 1997, Karapate 2011) provides further information on the relationships between variables and the underlying assumptions.

It emerges from our last hypothesis which relates the decisional latitude and the degree of satisfaction is not validated by our data. To justify this gap between our results and those of other authors who inspired us in the 
formulation of this hypothesis, it seems to us to be related to the different characteristics of our samples and to the type of investigation.

\subsection{Relationship between Turnover and Job Dissatisfaction}

Very few studies have been conducted on the relationship between turnover intention and employee dissatisfaction in the ICT sector (Murrar and Ahmad, 2013). These studies do not directly test the link between departure intent and employee satisfaction, they offer a more or less exhaustive list of the factors that cause agents to leave the company. The results reveal that the employee leave the company because they are poorly paid, undervalued, less appreciated, overused and exploited. The results of this study indirectly show that there is a positive relationship between poor working conditions and the turnover intention. Thus, "employees who feel they are under-rewarded by their work will have to try to restore balance by reducing efforts and increasing, for example, absenteeism, by coming late to work.

Muchinsky and Tuttle (1979) analysis the relationships between these two built in a meta-analysis they conducted on over 150 articles about the determinants of turnover intentions. Aggregated results reveal that there is a negative relationship between employee satisfaction and their intentions of turnover. The authors show, on the basis of the results of the Hulin (1966) study, that the average satisfaction score of employees who left the organization is significantly weaker than those who stayed.

The primacy of employee satisfaction in explaining intentions and turnover is also highlighted by more or less recent studies. Lambert et al (2001) claim that employee satisfaction is the best determinant of the intent to turnover. Alfonso Sousa-Poza and Andres A. Sousa-Poza (2000) corroborate this argument in demonstrating that "... some dimensions of employee satisfaction may be the better determinants of mobility at work .... ". Similar results had already been found by Rose and Hulin (1985) who argued that "overall employee satisfaction alone accounted for $45 \%$ of the variance in decisions to leave the organization. " Griffeth and al (2000) corroborate the argument above by demonstrating that overall job satisfaction was the main determinant of the willingness to leave the firm compared to other attitudes at work. The above results confirm those found by Shields and Ward (2001) who found that job satisfaction was the most important variable that determines the intention to leave work. By abounding almost in the same direction, Yucel and Bektas (2012), based on the results of previous studies (Hellriegel and Slocum, 2004; Wagner and Hollenbeck, 2005; Smith et al., 1969) argue that dissatisfied employees higher levels of turnover and absence than those who are satisfied. Karatepe and Uludag (2007) corroborate this argument by stating that "contact employees who exhibit low levels of satisfaction and a low level of emotional attachment to their organization are always thinking about leaving their organization." However, Lam et al (2001) and Jang and George (2012) argue that there is a significant negative relationship between employee satisfaction and the intention to leave the firm. Yang (2008) has almost to the same effect by demonstrating that employees who have a high level of satisfaction are more motivated to stay with their organization. Ahmad et al (2012) argue that "job satisfaction and intention to leave the organization are correlated innate, job satisfaction negatively affecting the willingness of employees to leave organizations ". Hom et al (1992) cited by Khiljia, Xiaoyun Wang (2007) demonstrate that there is a positive linear relationship between the turnover decision and the dissatisfaction workers. Wong (1989) cited by Ahmad et al (2012) corroborates this argument by proving that the more teachers are dissatisfied with their work, the higher their level of attachment organizational decline; which forces them to look for other job opportunities elsewhere. Singh and Loncar (2010) go in the same direction, concluding that the intentions to leave an organization decrease with increasing wages and vice versa (Dailey and Kirk, 1992; Motowildo, 1983). Chan Yin-Fah et al (2010) arrive at almost the same conclusions by demonstrating that the more satisfied employees are, the more they will focus on their organization and will think little or nothing about leaving their current jobs. Building on the results of previous studies, we therefore formulate the following hypothesis:

H1: there would be a negative relationship between job dissatisfaction and turnover

\subsection{Moderator Role of Socio-Demographic Variables}

Muchinsky, Tuttle (1979), Jang and George (2012) recognize that age, gender, seniority, educational level, household size and family responsibilities are sociodemographic variables that may explain the intention of turnover. Based on these results and taking into account the context of the study, we decided to examine the moderating effect of the following variables:

Several authors argue that turnover intentions vary significantly in seniority of employees (Chia-Shang Chen, 1985, Gao-Liang Wang and al, 2012). These results were confirmed by the meta-analysis by Muchinsky and Tuttle (1979). The authors argue that in all seven studies dealing with the relationship between turnover and seniority they analyzed, 
seniority was negatively correlated with the intention to leave an organization. The conclusions of Mangione's study (1973) corroborate the above results by stating that seniority of employees was the best determining their turnover.

The probable explanation is related to the fact that the number of years within an organization is interpreted as an investment in the leadership of the employees (Valle and Perrewe, 2000). The fear of discovering new horizons and new work experiences may discourage them from leaving their current organization.

The study conducted by Ahmad (2002 and 2003) seems to contradict the results of previous studies. The author finds that managers discriminate against former agents, which could push them to higher turnover intentions. Following Ahmad's arguments, it can be concluded that former employees would express more turnover intentions than young people. Indeed, as newly hired employees know that promotion is often a function of seniority in some companies, they could accept a career in their company. They could work hard, confirm their performance, deserve promotion and even access the position of responsibility. However, they may be more satisfied than the old ones, for whom the possibilities of changing and changing their salaries are limited.

Several empirical studies also recognize the importance of seniority as a factor moderator of relationships between employee satisfaction and intentions to leave (Ferriset al., 1987; Hackett, 1990; Bender and Heywood, 2006; Cossette and Gosselin, 2012). The aggregate results from these studies show that the more satisfied employees are, they have less likely to leave because they have a long history in their companies.

The argument above is classic. Experience shows that promotions and other benefits are often awarded based on seniority of employees. The long-serving employee has had the opportunity to progress up the ranks; receiving benefits related to his rank (in terms of training, compensation, etc.) and would therefore be more involved in the management of his career. All of these elements increase her level of satisfaction and attachment to the company so that it is difficult for her to leave the company due to numerous barriers to exit (loss of privileged status and other benefits). In fact, employees who have worked for an organization for a long time develop an emotional attachment to it, and therefore tend to be attached to it, especially since their satisfaction levels are high (Yucel and Bektas, 2012). On the basis of the arguments above, we therefore formulate the following hypothesis:

$\mathrm{H} 2$ (a): The relationship between job dissatisfaction and turnover would be higher than for former employees.

The human capital theory holds that the more skilled workers are the more they become productive (Becher, 1964). Therefore, highly educated workers and highly skilled people will also naturally be more demanding than others in terms of wage demands and better working conditions. The inability of businesses to meet their requirements can create frustrations for these employees and lead to leaving their current job. Driven by their qualifications, these employees find themselves able to find other job opportunities that match their status of the recent studies on the relationship between turnover intentions and level of study confirm these facts. Ying-Cheng Chen (2001) quoted by Liang Wang et al (2012) shows that more educated employees would be more stressed by poor working conditions and react directly to dissatisfaction by exhibiting very high rates of turnover. The level of study can also have an interactive effect on the relationship between job dissatisfaction and turnover. So, more employees are dissatisfied the less likely they are to leave their businesses because they are high levels of education. In fact, employees with a high level of education sometimes occupy high-level positions (Hersh, 1991). The monetary and non-monetary benefits they derive from these positions are high compared to other categories of employees. As a result, they would also display high levels of dissatisfaction, discouraging them from remaining in the service of the category. Indeed, in the absence of the universities and higher institutes that formerly formed, training on the state through seminars increases the level of employees they can brandish with respect to the several institutions that recruit on the basis of experience.

Even to continue to enjoy the same benefits (Theodossiou and Vasileio, 2007). The arguments above allow us to define the following hypothesis:

H2 (b): The relationship between job dissatisfaction and turnover would be higher for more educated employees than for the least educated

There are very few studies that test the link between employee dissatisfaction and turnover using the gender variable as an interactive variable of this relationship (AlfonsoSousa-Poza, Andres A. Sousa-Poza, 2007). The few studies that exist are very successful often with mixed or even controversial results (Khiljia and Wang, 2007). Indeed, some studies outright deny the existence of a prior relationship between gender and turnover while others show that gender is an important variable in the study of turnover. Campbell and Campbell (2003) cited by Khiljia and Wang (2007) have found that gender had no moderating effect on the relationship between job dissatisfaction and turnover. Booth and Francesconi (1999) cited by Alfonso Sousa-Poza and Andres A. Sousa-Poza (2007) reveal that turnover rates are similar in men as in women. Other studies, however, postulate the existence of a significant relationship between 
turnover and gender. The results of the studies of Cotton and Tuttle (1986), Weisberg and Kirschenbaum (1993) recently taken over by Khiljia and Wang (2007) show that women were more motivated to leave their jobs than men because of job dissatisfaction. Kuo-Yang Wang (2002) cited by Gao Liang Wang et al (2012) corroborate these findings and argue that women exhibit higher rates of intention to leave than men. The results of Elaine's studies (1997) and Khatri et al (2005) cited by Khiljia and Wang (2007) come to conclusions contrary, stating that it was men who exhibited significantly higher turnover when they are dissatisfied with the working conditions. However, these results can be put into perspective by the arguments from the context of this study. In fact, Tunisia, like most developing countries, is characterized by strong gender inequalities, with women scarcely accessing job opportunities compared to men (Khanchel and Ben Kahla, 2018). From then on, they would almost naturally attach themselves to current job positions regardless of their level of satisfaction. The gender can also play an interactive role between satisfaction and the employee's intention to leave. In fact, the more satisfied the employee is with his job, the less likely she is to quit her job as a woman. This reasoning makes sense only when it applies to certain functions within firms, functions for which women have a comparative advantage over men. The latter shine by their honesty and bravery and end up winning through a job well done. This is why they receive cash bonuses as well as monetary and non-monetary rewards. Some of them manage to climb the ranks of the hierarchy until becoming managers or heads of agencies, functions formerly reserved for men. The awards thus received value women, dramatically increase their level of satisfaction compared to their male colleagues and predispose them to stay in their companies. This allows us to formulate the following hypothesis somewhat outside the existing theory.

$\mathrm{H} 2$ (c): The relationship between job dissatisfaction and turnover would be higher for men than for women.

Age is the most studied variable related to either job dissatisfaction or as a mediator of the relationship between employee dissatisfaction and turnover. Muchinsky and Tuttle (1979) reveal that nine studies of the eleven they spent review confirm that there is a negative relationship between age and turnover. The review of previous studies by Yucel and Bektas (2012) shows that there is "a positive linear relationship between age and job satisfaction ... "(Herzberg, Mausner et al,1987; Rhodes, 1983). Yucel and Bektas (2012) and Bedeian et al (1992) and Jang and George (2012) almost the same argument when they say that "older employees consider years spent serving an organization as an investment making their current job very attractive (Mathieu and Zajac, 1990, Lew Tek Yew, 2007).

Therefore, they would be subject to a psychological barrier that would prevent them from their current organization and go to others. This finding would still be true in the the socio-economic context of the country where there are no retirement benefits is slowing down. As a result, older employees are forced to hang on to their jobs when they still have strength. Young people, meanwhile, would express a high mobility at work (intention to leave) link to the fact that they are at the beginning of their career. Young people are therefore in an active search process for a job that meets their expectations in other organizations (Theodossiou and Vasileio, 2007, Mohsina et al, 2013). Age can also play an interactive role in the relationship between employee satisfaction and intention to depart. In fact, the older the employee, the greater the negative effect of dissatisfaction on the turnover. Older employees attach more importance to job stability and tend to have higher levels of satisfaction. As a result, their starting intentions will be more negatively affected by their level of satisfaction compared to youth (Martins, Eddleston \& Veiga, 2002).

However, older employees often gain access to the highest hierarchical positions, receive high salaries and are therefore more concerned about employment stability objectives. As a result, these employees have lower wage demands and often have high levels of satisfaction compared to youth. These employees are either not or not sensitive to poor working conditions and cling to their current job because they know that, given their age, it will be very difficult for them to find another job (Ferlie and Rosenberg, 2008). All of these arguments confirm that the relationship between job dissatisfaction and turnover will be more negatively pronounced than older employees. The arguments above we therefore make it possible to formulate the hypothesis below.

H2 (d): The relationship between job dissatisfaction and turnover would be higher for younger employees than for older employees.

\section{Methodology}

We present respectively the techniques used to collect and process the data as well as the measurement of the variables mobilized in this study.

\subsection{Sample and Data Collection}

The data was collected in three stages: the qualitative survey, the pre-survey and the investigation itself. The qualitative survey was conducted with 45 employees in TIC Sector. The pre-survey was conducted with 45 employees and its results (mean $=3.26 ; \mathrm{SD}=.65$ ) allowed us to determine the size of the sample in using the formula opposite (Vernette 
et Giannelloni, 2012) : $\left.\mathrm{n}=\left[\begin{array}{lll}\mathrm{z} & \alpha / 2 . & \mathrm{s} \\ \mathrm{X}\end{array}\right] / \mathrm{e}\right]$. In applying this formula, we found a total sample of 45 employees.

We contacted CEO in advance to obtain permission to administer the questionnaire to their employees.

For some structures, the questionnaires were filed with the human resources, who then distributed it to the staff. The investigators were trying to explain to these officials the objectives of the study and especially the methods of his administration.

The pre-investigation was conducted on the premises of the Tunisian companies. Two objectives were assigned to the pre-survey: test the questionnaire and determine the sample size. Views from employees allowed us to correct and / or to remove certain ambiguous items

With $\mathrm{n}=$ sample size; $\alpha / 2$ = value of the normal distribution equal to $1.96 ; \mathrm{Xt}=$ Standard deviation of the sample our case is $0.65 ; \mathrm{e}=$ the error that the researcher agree to commit equivalent, often to 0.05 . This formula makes the sample size depend on its standard deviation, which is not known a priori. To solve this problem, the researcher is using the standard deviation of a previous study conduct a pre-survey and thus uses the standard deviation of this pre-survey. As part of this study, we had a pre-survey of 45 people because there had never been a study of either satisfaction or turnover in the context of the study. By replacing all these elements in the formula above, we get a sample of 45 in TIC Sector.

The choice of employees was made by proportional stratification. Thus, structures employing more employees were overrepresented in the sample. The employees were chosen on the basis of their seniority and function. Only employees with at least a minimum of three months seniority were invited to participate in the survey.

\subsection{Variables Measurements}

Considered as the factors contributing to autonomy in decision-making, we will first interpret using variables the variables of the decisional latitude followed by the ACP, then, in a second step, we will analyze the behavior of our respondents.

\section{A. Decision latitude}

It is to interpret in the table below the point of view of the individuals on the decisional latitude. For this purpose, three variables allow us to analyze them. These are: the current decision making for the smooth running of the company, the consultation of the superiors before and after the implementation of the decisions to be taken. The results of the survey are shown in Table 1.

Table 1. Decision latitude

\begin{tabular}{|c|c|c|c|c|c|c|c|c|c|c|c|c|}
\hline \multirow{2}{*}{$\begin{array}{c}\text { Appreciation } \\
\text { Latitude } \\
\text { decision }\end{array}$} & \multicolumn{2}{|c|}{$\begin{array}{c}\text { not agree at } \\
\text { all }\end{array}$} & \multicolumn{2}{|c|}{ Disagree } & \multicolumn{2}{|c|}{$\begin{array}{l}\text { A little bit of } \\
\text { agreement }\end{array}$} & \multicolumn{2}{|c|}{ Agreement } & \multicolumn{2}{|c|}{$\begin{array}{l}\text { Totally } \\
\text { agree }\end{array}$} & & \\
\hline & Freq. & $\%$ & Freq. & $\%$ & Freq . & $\%$ & Freq. & $\%$ & Freq. & $\%$ & & \\
\hline $\begin{array}{l}\text { Current decision } \\
\text { making }\end{array}$ & 2 & 1.6 & 5 & 4.1 & 19 & 15.6 & 63 & 51.6 & 33 & 27.0 & 1,463 & -0.990 \\
\hline $\begin{array}{l}\text { Consultation of the } \\
\text { hierarchy after } \\
\text { decision making }\end{array}$ & 1 & 0.8 & 3 & 2.5 & 11 & 9.0 & 74 & 60.7 & 33 & 27.0 & 2,886 & -1.091 \\
\hline $\begin{array}{l}\text { Consultation of the } \\
\text { hierarchy before the } \\
\text { decision making }\end{array}$ & 14 & 11.5 & 18 & 14.8 & 33 & 27.0 & 38 & 31.1 & 19 & 15.6 & -0.769 & -0.346 \\
\hline
\end{tabular}

Source: our surveys

Reading the table above shows us that a high proportion of people think of the current decision making, the consultation of the hierarchy after the decision entirely agree or simply agree.

When analyzing the coefficients of asymmetry and flattening, it can be seen from the table that, with the exception of the variable "Consultation of the hierarchy before decision-making", all asymmetry coefficients have negative values, which means that, compared to the normal distribution, the observations are on the whole rather concentrated towards the strongest values. With regard to the concentration coefficients, the variable "Consultation of the 
hierarchy before decision-making" is negative, which means that for some variables, the observations are weakly concentrated, whereas for others opinions are rather divided. Moreover, the most significant variables in decision latitude: "Current decision-making" and "Consultation of the hierarchy after decision-making". The dominant features should be determined. For this, we carried out a principal component analysis with VARIMAX rotation on the 3 items of the scale. The results are shown in Table 2.

Table 2. ACP on the measurement scale of the decision latitude

\begin{tabular}{cccc}
\hline items & FACl & FACl & Com \\
\hline Common decisions & $\mathbf{0 . 8 6 7}$ & & 0.765 \\
Consultation of the hierarchy after decision making & $\mathbf{0 . 8 6 8}$ & & 0.765 \\
Consultation of the hierarchy before the decision making & & $\mathbf{0 , 9 9 4}$ & 0.988 \\
Percentage of variance explained & 50.171 & 33.770 & \\
Percentage of cumulative explained variance & 50.171 & 83.941 & \\
Alpha (á) from Crombach & .6868 & &
\end{tabular}

\section{Source: our surveys}

The decision latitude variable is apprehended using three items all evaluated on five-point interval scales. The CPA highlights two factors with eigenvalues greater than 1 and accounting for $83.9 \%$ of the total variance. On the basis of the KAISER criterion, these two components must be retained. The value of the Crombach alpha coefficient measured on the items forming the component is 0.6868 for the items forming the first component. Variables forming the same factor therefore have good internal consistency, since the recommended minimum value of Crombach's alpha is 0.60 .

The first dimension is represented by the factorial axis F1 which is strongly correlated with the first two items. It is a factorial axis that represents autonomy in decision-making. The first factor F1 is named "Decisional independence" and the second F2 is named "Decisional dependence" .

A. Behavior and Attitudes of Supervisors

\section{Behavior of supervisors}

The following table analyzes the behavior of supervisors in companies:

Table 3. Behavior of supervisors

\begin{tabular}{|c|c|c|c|c|c|c|c|c|}
\hline \multirow{2}{*}{$\begin{array}{c}\text { Appreciation } \\
\text { Behavior }\end{array}$} & \multicolumn{2}{|c|}{ weakly } & \multicolumn{2}{|c|}{ Moderately } & \multicolumn{2}{|c|}{ strongly } & & \\
\hline & Freq. & $\%$ & Freq. & $\%$ & Freq. & $\%$ & & \\
\hline Execution of tasks without superior's opinion & 17 & 13.9 & 65 & 53.3 & 40 & 32.8 & -0.722 & -0.222 \\
\hline Integration within the company & 15 & 12.3 & 60 & 49.2 & 47 & 38.5 & -762 & -1.353 \\
\hline Degree of responsibility in achieving objectives & 10 & 8.2 & 64 & 52.5 & 48 & 39.3 & -0.631 & -0.315 \\
\hline
\end{tabular}

\section{Source: our surveys}

Reading the table above shows us that a high proportion of people estimate all variables moderately.

When we analyze the coefficients of asymmetry and flattening we realize that all the coefficients of flattening and of asymmetry have negative values, which means that, compared to the normal distribution, the observations are on the whole rather concentrated towards the strongest values. 
Attitude of supervisors

Table 4. Work attendance

\begin{tabular}{cccc}
\hline Attendance at work & Absolute frequencies & Relative frequencies & Cumulative frequency \\
\hline not agree at all & 2 & $1.6 \%$ & $1.6 \%$ \\
Ok & 34 & $27.9 \%$ & $29.5 \%$ \\
Totally agree & 86 & $70.5 \%$ & $100 \%$ \\
Total & 122 & $100 \%$ & \\
\hline
\end{tabular}

\section{Source: our surveys}

The results obtained using frequencies show that there are as many individuals 86 or $70.5 \%$ who completely agreed on the issue of attendance at work. Indeed, the studies on the behavior of employees are not close to our results. But what can explain the fact that in our context, the divergent results compared to those of previous studies?

It is in our context a specific category that we realized our study. Whereas for previous studies, it concerns employees in general across all categories.

Table 5. Compliance with hierarchy instructions

\begin{tabular}{cccc}
\hline Compliance with instructions & Absolute frequencies & Relative frequencies & Cumulative frequency \\
\hline Not important & 4 & $3.3 \%$ & $3.3 \%$ \\
Important & 44 & $36.1 \%$ & $39.3 \%$ \\
Very important & 74 & $60.7 \%$ & $100 \%$ \\
Total & 122 & $100 \%$ &
\end{tabular}

\section{Source: our surveys}

Compliance with the instructions of the hierarchy is essential for any employee who seeks his well being and wishes to pursue a career in a company. Of 122 supervisors, 74 or $60.7 \%$ gave a very important opinion of the respect of the instructions given by the hierarchy. In his book Peretti (1994) comes to the conclusion of his study according to which, the behavior of the leader is much more the factor which influences the importance of the instructions of the decentralized tasks.

Table 6. Satisfaction of the quality of work

\begin{tabular}{cccc}
\hline Quality of work & Absolute frequencies & Relative frequencies & Cumulative frequency \\
\hline Not at all satisfied & 5 & $4.1 \%$ & $4.1 \%$ \\
Moderately Satisfied & 46 & $37.7 \%$ & $41.8 \%$ \\
Very satisfied & 71 & $58.2 \%$ & $100 \%$ \\
Total & 122 & $100 \%$ &
\end{tabular}

\section{Source: our surveys}

The quality of the work makes it possible to establish a good or bad relation between work and degree of satisfaction. The following question is asked: Are you satisfied with the quality of the work you are doing? 71 out of 122 or $58.2 \%$ were very satisfied with the quality of the work they do. Thus, employees who take on the most strategic tasks find it rather interesting and take it with great satisfaction. This may explain the regular presence at work.

\section{Findings}

The main objective of this study is partly achieved since we needed to identify and analyze the behavior of supervisors in companies. Thus, this section seeks to make analyzes (test hypotheses), either to describe associations of variables. Thus, the first point will consist in discriminating the satisfaction factors in the Tunisian companies in TIC Sector, the second point is devoted to the verification of the hypotheses. 


\subsection{Sociodemographic Characteristics, Dissatisfaction and Turnover}

The results from this study reveal that $74 \%$ of employees are men and only $26 \%$ of women. The majority of employees (43\%) are between the ages of 21 and 30 and $42 \%$ are between 31 and 40 years old. $85 \%$ of employees have a good level of education, $45 \%$ of graduates versus $40 \%$ of graduates. Most employees, $59 \%$ are married against $36 \%$ of single people. $3 \%$ of employees are divorced while $2 \%$ are separated. The frontline is the majority of employees surveyed, $62 \%$ of the cases (31\% engineers, $19 \%$ analysts, $12 \%$ technicians). The results reveal that $45 \%$ of employees work for a period of between 1 and 3 years. Employees with a seniority of less than one year represent $15 \%$ of the sample compared to $5 \%$ of employees with seniority of 10 years or more. $86 \%$ of employees say that they do not maintain any relationship of kinship or friendship with the CEO. Do socio-demographic characteristics influence employees' intentions to leave? The answer to this question was provided through an equality test of the two means and a one-way analysis of the variance test. The dependent variable refers to the total average index resulting from three items that measure their starting intentions. Therefore, the results indicate that data supports variance analysis and equality test two averages confirming that the different variances are equal in the population of employees (Giannelloni and Vernette, 2012). Indeed, the materiality thresholds relating to the Levene statistic are almost all greater than 0.05 except for the variable civil status of employees. The average starting intention is high, 3.77. Departure observed population is relatively low or almost non-existent compared to the intention to leave.

This means that employees do not have enough opportunities to realize their intentions of departure. This is partly due to the scarcity of higher-paying jobs and a surplus of supply on demand in the labor market. Companies are almost in a monopoly position and dictate the terms and conditions of work to potential employees (Rouleau et al, 2012).

The results from the analysis of variance indicate that the original intent is influenced by the age of the employee $(\mathrm{F}=$ $-3.27, \mathrm{p}=.012)$ and the seniority of employees $(\mathrm{F}=5.23, \mathrm{p}=.000)$. These results are contrary to those found by Yildiz et al (2009) and Cossette and Gosselin (2012) who argue that no variable demographics does not influence turnover intentions. Results from Duncan's test (see Appendix) show that the youngest employees exhibit intentions to leave high $(M=4.4$ for employees under age 20, $M=3.8$ for employees whose age is between 21 and 30) than seniors ( $M$ $=2.6$ for employees whose age varies between 51 and 60 years). The underlying argument is about job security for adults who no longer have multiple job opportunities. This barrier predisposed them to stay with their current employer.

The results of this study indicate that turnover intentions are a function of the seniority of the employees $(\mathrm{F}=5.23, \mathrm{p}$ $=.000)$. Indeed, the employees having spent less than one year $(\mathrm{M}=4)$ and those whose seniority is between 1 and 3 years $(M=3.81)$ exhibit strong intentions to leave their positions compared to those who have worked for 10 years or more $(M=2.75)$ as well as those whose average seniority is between 7 and 9 years old $(M=3.14)$. Such behavior is explained both by security employment and attachment to the company. Newly hired employees are somewhat fragile because they have not signed indefinite contracts. As a result, they are aware that each downsizing policy will target them first. Older employees, on the other hand, enjoy the benefits of seniority (bonuses, promotion) and have an almost exclusive attachment. Indeed, these agents are sometimes also the most experienced, thus constituting an intangible asset.

\subsection{Dimensions of Job Dissatisfaction and Nature of Relationship with Employee Departure Intent}

The results from the measurement model and the structural model show that the model as well as the specified reflects the data fairly well $(\mathrm{CFI}=.93$; IFI $=.93$, TLI $=0.91$; RMSEA $=.06)$. In indeed, all the adjustment indices show satisfactory values (Brown, 2006; Malhotra et al, 2010). The table below gives us more information.

The results from the measurement model show that each variable is statistically related the latent construct to which it was supposed to be attached. All dimensions pertaining to employee satisfaction have widely standardized structural coefficients higher than 0.05 as well as capital gains well above 1.96. The percentage of variance explained by each dimension is high and varies between $27 \%$ (relationships between colleagues and the nature of work) at $49 \%$ (for circulation of information). The same conclusions can be drawn for variables that measure intention to leave their position.

These exhibit high structural coefficients and t-values with percentages individual explained variance ranging from 53\% (intent 5) to 67\% (intention1). These some results show that the estimated model exhibits validity properties convergent and discriminant (Vieira, 2011, Lings and Greenly, 2005, Fornell and Larcher, nineteen eighty one ; Anderson and Gerbing, 1988). These results can be viewed on the diagram below.

The results from diagrams 5 and 6 and those in the table above show that the employee satisfaction is a multidimensional construct consisting of 43 items subdivided into ten main dimensions (see diagram 5): compensation, 
relations with colleagues of the same rank, promotion, working conditions, training, circulation of the information, relationships with the supervisor, job security, the nature of the job as well as the love of work. The contribution of each dimension to the explanation of the feelings of satisfaction is appreciated by its structural coefficient, the dimensions presenting high structural coefficients being also the most important (Karapate et al, 2005).

Traffic and information sharing is positioned first $(\chi=.80)$ dimension of employee satisfaction. This dimension refers to the existence and use of formal channels to communicate information. It also relates to the possibility of employees giving their opinion on the management of their business.

This dimension also informs that everyone is well informed about everything happens in the organization. This dimension also highlights the importance of between the departments. The arguments above remind managers to promote information sharing so that important decisions are made in a timely manner.

Regular inter and intra department meetings are a good opportunity to put all the world aware of the smooth running or not of the organization. These meetings are an opportunity for managers to report and unveil future plans for development. Employees can also take advantage of these meetings to give their opinions and proposals. They can also take the opportunity to make a state of their prerogatives, to set out the difficulties to which they are subject in their work and the major advances they have made.

Everyone's access to information is the best way for every employee to be aware of what's going on in their job, to understand the big issues, and especially to behave accordingly. This dimension makes the company aware of the need to adopt "market orientation" to survive in the competitive environment. In this perspective, the company must collect information from the market to identify the needs and preferences of customers, identify the likely actions of competitors, and share this information within the organization so that actions are taken (Kohli and Jaworski, 1990).

The above arguments raise awareness among managers to promote dialogue, transparency and effective communication within their institutions (Sarker, 2013). The flow of information is of paramount importance for organizations that share little or no information with other stakeholders in their immediate environment. Indeed, some structures are comparable to "black boxes" where the information is only available from the general management; other employees being considered as performers who are often uninformed about the management of their business. Some organizations hesitate to share information with their employees or with other external stakeholders (researchers, auditors, among others). Some organizations even believe that the average employee understands nothing of the organization, that they have nothing to add or change to existing procedures.

Such a design can have negative repercussions. Indeed, lack of transparency and useful information can reduce the ability of employees to focus on their business. This is justified by the fact that poorly informed employees would find it difficult to link their own efforts to the achievement of their institution's goals (Ross \& Denzer, 2011).

Work safety and compliance with the law is positioned as the second dimension $(\chi=.78)$ of employee satisfaction. This dimension relates in particular to the respect of the commitments assigned to employers in the labor code, the signature of the contract of indefinite duration by the employees as well as the stability of their employment. The primacy of job security is explained by the insecurity that characterizes almost all sectors of employment.

The importance of job security had already been highlighted in the explanation of employee satisfaction in some previous studies. The results of the International Social Program (1989) survey as well as those of the Moguerou study (2002) taken up by Theodossiou and Vasileio (2007) all show that safety at work is the most important determinant of job satisfaction. The importance of workplace safety is that it allows employees to guard against future uncertainty, to plan and to envision long-term investment plans.

The love of work refers to whether or not employees find their work interesting and therefore proud of it. A job is interesting for the employee if it allows him to highlight his talents, knowledge and expertise. The love of work predisposes the employee to give the best of him to work. This characteristic is important for the ICT sector, where several functions are routine, often leading to boredom and stress.

Because employees work under pressure, they may become discouraged and leave their post. Only the love and attachment they have to their workstations can reduce significantly these imperfections. The pride that employees derive from work can also to help strengthen the love of work. For example, some structures have instituted a form of public recognition of their employees that they prefer as "best cashier, best agent of the year". Even though these rewards may not have a significant financial impact, they contribute to strengthening the image and personal reputation of the employees concerned. This recognition could be used, the in the event of future promotions. It can also serve as a signal of competence to the place of other organizations that are looking for a skilled workforce. 
Training and staff development is the sixth dimension $(\chi=.59)$ of the employee satisfaction. This dimension refers to access to training that confers new knowledge on employees, knowledge that prepares them for future higher positions. This dimension also highlights the fact that employers provide advice to employees in relation to their career development. The importance of such training is justified by the fact that there are now only a few universities and higher institutes that specialize in ICT (Murrar and Ahmad, 2013). Most employees have general knowledge of management and economics. Training increases the efficiency of employees, increases their adaptability and allows them to easily adopt new technologies. Staff training encourages employee satisfaction and retention. Indeed, the various training received allows employees to better absorb the organizational culture, to build a story with the company and to express little or no intention to leave (Khanchel and Ben Kahla, 2018).

By therefore, trained employees are also the most competent because they understand their tasks better. These trainings prepare them to assume great responsibilities in the future and predispose them not to leave their posts. Indeed, there is a positive relationship between training received and increased self-esteem among employees (Pityn and Helmuth, 2007).

Working conditions constitute the sixth dimension $(\chi=.59)$ of job satisfaction. This dimension refers to the presence of computerized management, the availability of tools and work equipment, a good distribution of tasks and the condition of the buildings housing the offices. The importance of computerized management is due to the fact that it facilitates the work of the employees by allowing them to save time. The computerization of management promotes the speed of operations while preventing employees from making mistakes. The presence of work tools and other equipment also helps improve employee performance. Indeed, as the work of credit officers takes place in the field, they should have the motorcycles, vehicles and other logistical elements that make their task easier. These logistical means remind us that employees are not machines or indefatigable robots (Sarker, 2013).

The importance of the division of labor is that employees are often overloaded, overwhelmed because they are required to perform multiple tasks at a time. A clear description of the tasks would prevent them from dispersing and devoting themselves to the essential tasks related to their main mission. The clear division of responsibility (job description) is without a doubt the perfect remedy that would free employees from their daily pressure and which predisposes them to express a high level of satisfaction (Sarker, 2013).

Promotion is the seventh dimension $(\chi=.58)$ of employee satisfaction. This dimension refers to the speed with which employees are promoted, the respect of the criteria of competence of the employees in the granting of the promotions as well as the respect of the criteria described in the guide of the promotions. The speed of the promotion process is a remedy to the discouragement and dissatisfaction of competent employees who occupy lower positions. In fact, promotion can encourage the satisfaction, loyalty and commitment of the employees thus promoted. For employees, promotion is seen as recognition of the work done. It is also seen as a source of pride and a symbol of professional and social success. The focus on the skills of agents highlights the integrity, impartiality and rigor that must accompany the entire promotion process. Only those employees who have demonstrated proven competence in the performance of their work or who have excelled in a particular field should be promoted. The application of the criteria defined in the promotional document makes it possible to avoid arbitrariness by favoring, for example, persons who are close to the management. This is all the more important in the context of the study, where social and clan relations may sometimes prevail over all other objective criteria.

Managers should therefore understand that poorly distributed promotions can discourage competent employees, cause their dissatisfaction as well as their departure from the institution and vice versa. This suggests that a good system of promotion allows structures to gradually acquire human resources competent to ensure the continuity of the organization even in the absence of founders. Indeed, it is "beautiful to have a charismatic founder but also you must have a reservoir of skilled labor ready to insure ". All this can only be possible thanks to a good promotion system.

The relationship and respect dimension towards colleagues at the same level is positioned as the last dimension $(\chi=.53)$ of employee satisfaction. This dimension relates to the quality of the relationships between employees, the mutual respect that characterizes these relationships, the predisposition they have for building strong bonds of friendship with each other and the appreciation they have for each other.

The competition of all the structures is necessary so that the operation proceeds perfectly. All of this is only possible if employees cultivate good relationships with each other. Otherwise, they will set traps, multiply harassment, affect the speed of operations and block the system and performance of the institution. This implies that performance implies strong cooperation between employees. Managers should strive to develop collaborative relationships between employees. It is therefore a question of bringing out an esprit de corps between the employees, to push them to work 
together, for example by setting up working groups by departments and to create festive occasions outside working hours to promote greater familiarity between the employees.

Results from the structural model show that employee satisfaction influences negatively and statistically the employees' departure intentions $(\gamma=-.32, \mathrm{t}=-5.51, \mathrm{p}=.000)$. These results confirm our first hypothesis, stating that the more satisfied employees are with their work, the less likely they are to leave their job (Arndt et al, 2006, Muchinsky and Tuttle, 1979, Porter, Steers et al, 1974, Wei et al. Tian-Foreman, 2009, Jange and George, 2012). These findings are consistent with the findings of several previous studies that indicate that employee satisfaction has a significant influence on employees' intentions to leave (Griffeth et al, 2000, Egan, Yang et al, 2004, MacIntosh and Doherty, 2009; Leisanyane and Khaola, 2013). The results of this study are directly related to the conclusions of Muchinsky and Tuttle's (1979) meta-analysis, which showed that employee satisfaction, plays a prominent role in explaining intentions of departure as well as effective departures of employees. In fact, when employees become dissatisfied with their work, they have intentions to leave, which are often followed by effective departures (Hom et al, 1992, Lyons and O'Brien, 2006, Koch and Steers, 1978). Cheng-Ping Chang and Wei-Chen Chang (2008) corroborate the above argument by showing, based on the results of a study conducted by Watson Wyatt Worldwide, that "58\% of employees leave their company because they are dissatisfied with their salary while $48 \%$ of employees abdicate because they are dissatisfied with the management system of their institution and the lack of promotion opportunities ... ". Alfonso Sousa-Poza and Andres Sousa-Poza (2007) and Clark (2001) argue that employee satisfaction is the best determinant of the behavior of future departures in firms. The same argument is repeated by Lambert et al (2001) who show that employee satisfaction has the most significant impact on employees' intentions to leave. The authors show that the effect of employee satisfaction is twice as great as that produced by the other explanatory variables. The results of the study by Chan Yin-Fah et al (2010) go in the same direction by proving that $20 \%$ of the total variance of employees' departure intentions is explained by low levels of employee satisfaction.... The study by Vidal et al (2007) has the same result, demonstrating that the satisfaction of expatriate employees was one of the major determinants of their initial intentions. Ryan and Sagas (2009) corroborate the above argument by proving that the intentions and actual departures of managers and marketing agents in the sports sector are mainly explained by their salary. Kautonen, Hytti et al (2012) show that employees who are satisfied with their work could delay their retirement and prolong their career because they find their work pleasant and attractive. The results of Hanish and Hulin (1991) indicate that employees who are dissatisfied and who feel that their work is not important are more likely to leave their work using all the necessary means. In short, employees should be treated properly in terms of salary, promotion, among others. In this perspective, we must be reassured of their satisfaction in order to avoid that they are dissatisfied and they do not desert.

\subsection{Interactive Effects of Sociodemographic Variables}

The effect of socio-demographic variables on the relationship between employee satisfaction and their starting intentions are tested by three models.

The results from the table above show three different models. R2 adjusted for these models are respectively. 04 for the first and respectively .09 and .11 for the second and third models. Using the adjusted R2 as an adjustment criterion for these three models, we find that model (3) has the highest adjusted R2 compared to the other two. However, this model is more adjusted than the others. By therefore, we prefer it to the other two and so we base all the interpretations on this model. The results show that the independent variables explain $11 \%$ of the variance of departure intentions. The model is overall $\operatorname{good}(\mathrm{F}=6.04, \mathrm{p}=.000)$.

The results show that the level of education of employees influences positively and significantly turnover intentions ( $\beta$ $=.33, \mathrm{t}=2.04, \mathrm{p}=.04)$. Such results indicate that employees with a high level of education are more likely to leave their job (Bright, 2008, Hersch, 1991). These results are in contradiction with those of Borkowski, Amann et al, 2007)

who found that there was no statistically significant difference between nurses' initial intentions and their level of education. The results of this study, however, corroborate those found by Clark-Rayner and Harcourt (2000) in a study on the determinants of turnover behavior in the banking sector in New Zealand. The authors show that employees with high level of education are sometimes engaged in lower level credit, cashier, marketing officer). These employees are required to perform tasks routine and simple to the point that they end up finding their work boring and little stimulating. Driven by unemployment, they accept in spite of themselves, this work they consider as a temporary, transitional job, the time they find a job compatible with their qualifications in other sectors of activity.

In a studied context marked by scarcity and job insecurity better paid, the majority of employees agree, despite themselves, to take this job by lack of alternative. As Clark-Rayner and Harcourt (2000) have shown, we can therefore imagine that these employees are in a transitional stage and would not delay leave their job if they found a better job offer. The advent of news companies and the various state initiatives to recruit young graduates into the public service 
tend to confirm the strong predisposition of employees with a high level of study to leave their institutions. Indeed, almost all new banks have found most of their staff by voluntary poaching. These types of employees are interesting because they generate less transaction costs in terms of training; they are indeed almost ready for the task as they were already almost in the profession. For employees, banks offer better prospects in terms of pay, advancement in rank and value more employees to their entourage (in terms of image). Indeed, society would value more the status of the banker than that of an employee.

The results also show that employee satisfaction in interaction with the level negative and significantly influences their intentions of departure $(B=-.06, t=2.20, p=.02)$. These results reveal that if employees are more satisfied, they are less likely to leave their posts because they are higher education. This result confirms that the level of study moderates the intensity of the relationship between employee satisfaction and their intentions to leave. Indeed, employees with a high level of education and who are satisfied with the current conditions.

There is little or no intention to work compared to those with a low level of education. This result partially confirms our second hypothesis $(\mathrm{H} 2 \mathrm{~b})$.

Such results can be explained in light of the theory of equity. Employees who enjoy a high level of education are likely to occupy positions of great and high salaries compared to others (Hersch, 1991). By therefore, they intuitively exhibit high satisfaction rates (Theodossiou and

Vasileio, 2007) as well as low initial intentions (Borkowski, Amann et al, 2007) compared to other categories of workers. These findings confirm this thesis by showing, for example, that the level of satisfaction of managers under study was higher than all the other categories of employees surveyed. Koch and Steers (1978) corroborate the above argument by showing that employees with a high level of education easily access the best jobs and are very satisfied with their institution.

\section{Conclusion}

This survey has two objectives: to develop a scale to measure employee satisfaction and to identify links between job dissatisfaction and turnover (1) and test whether the variables socio-demographic factors are likely to moderate this relationship (2).

Results show that job dissatisfaction has an even greater impact on starting intentions that the level of education is high. Thus, the more an employee is dissatisfied with his job, the less he will develop intentions to quit his job. The results confirm that the level of education of employees moderates the relationship between job dissatisfaction and turnover. Indeed, the more employees enjoy high level of schooling, the more they attach to it and develop little or no no intention of departure depending on the positions of responsibility they occupy and therefore the high salary they receive.

These findings provide to CEO a managerial tool that identifies and responds to employees' needs and preferences adequate. The results relating to employee satisfaction are reminiscent of managers that they should first and foremost strengthen workplace safety. CEO should also invest in training of their employees. This training can take the form of modular seminars or diploma courses. Such an initiative has the advantage of giving trained workers who do their job properly and thereby give competitive now dedicated to competition. CEO should also involve their employees in decision-making and their give information related to the Quality of life in the workplace. This is a beginning of management by objectives, where employees know the objectives, participate in their definition and are motivated to achieve them. In the same vein, leaders should promote deserving employees and improve the work environment and pay conditions. In short, CEO is therefore invited to invest in their employees.

These investments can reduce the difference between the benefits employees receive and the efforts they invest in the work; which could gradually strengthen their attachment to their job. The satisfaction and dedication of the employees thus obtained will reduce intentions and other opportunistic behaviors result in deterioration in the quality of services and negatively influence retention and customer loyalty (Huey-Ming Tzeng, 2002).

The ability of the level of study to influence the relationship between employee satisfaction and departure intentions is both an opportunity and a challenge for Tunisian companies in implementing their employee career promotion and management policies. Employees with high levels of education should be valued and promoted as they are intangible assets that enable the organization to achieve its goals. By hypothesis, these employees would be more qualified and their level of satisfaction would make it possible to maintain them the longest within the company. Such employees should therefore receive specific treatment. Thus, when they are promoted and receive other monetary and non-monetary benefits, only justice is done. In return, they will focus on their job and will have little or no incentive to compete. CEO should also reflect on the nature and type of promotions that meet the needs of less educated employees 
(training, remuneration, credit) and enable them to realize themselves and develop their careers (Enzi Chang et al, 1999 quoted by Khan et al, 2013).

The contribution of this study to literature is twofold: first, it confirms that the level of education has a positive influence on employees' intentions to leave; this same variable tempers the relationship between departure intent and employee satisfaction.

The results sensitize to recruit employees according to their level and place them in positions they like. This could result in a exclusive attachment to their job with positive repercussions on the performance. Secondly, this study analyzes these links where employee studies in general, satisfaction and turnover intentions in TIC sector in particular, are virtually non-existent. The results therefore confirm the importance of human resources in the TIC sector and invite CEO to the valorization of their staff.

This study has some limitations, however. It only tests the interactive effect of sociodemographic variables on the relationship between employee satisfaction and original intention. A global study taking into account other organizational variables as the organizational commitment and loyalty of employees would come to enrich and complete the present results. This study does not analyze the direct influence of behavior of managers of on employee satisfaction. A study on the management style and employee satisfaction could also help to understand how the behavior of managers or directors (manager autocrat versus manager democratically) can influence the level of satisfaction of employees. The current study uses data collected from employees at a fixed time (after the events of 14 January 2011). We can therefore consider reproducing this study (but with the same variables measured) in a longitudinal perspective. So, we could obtain data at different years (panel data), which would allow the application of more sophisticated econometric techniques to account for possible estimation bias resulting from unobserved heterogeneity between different companies, the endogeneity of the explanatory variables or the dependence of the variables explained over time.

\section{References}

Ahmad B, Shahid M \& Zill-E- Huma. (2012). Turnover Intention : An HRM Issue in Textile Sector. Interdisciplinary Journal of contemporary Research in Business, 3(12), 125.

Ahmad M (2001). Bearers of change: the eld workers of NGOs in Bangladesh, Durham theses, Durham University, Available at Durham E-Theses Online: http://etheses.dur.ac.uk/4508/

Alexandrov A, Babakus E \& Yavas U. (2007). The Effects of Perceived Management Concern for Frontline Employees and Customers on Turnover Intentions Moderating Role of Employment Status. Journal of Service Research, 9(4), 356-371 https://doi.org/10.1177/1094670507299378

Al-Hawary S, Al-Qudah K \& Abutayeh P. (2013). the impact of internal marketing on employee's job satisfaction of commercial banks in Jordan. Interdisciplinary Journal of Contemporary Research in Business, January, 4(9),

Alniacik, Cigerim \& Akcin. (2011). Independent and joint effects of perceived corporate reputation, affective commitment and job satisfaction on turnover intentions. Procedia Social and Behavioral Sciences, 24(2011), 1177-1189 https://doi.org/10.1016/j.sbspro.2011.09.139

Anderson, J.C. \& Gerbing, D.W. (1988). Structural equation modeling in practice: a review and recommended two-step approach. Psychological Bulletin, 103(3), 411-423. https://doi.org/10.1037//0033-2909.103.3.411

Arndt A, Arnold T \& Landry T. (2006). The effects of polychronic-orientation upon retail employee satisfaction and turnover. Journal of Retailing, 82(4), 319-330 https://doi.org/10.1016/j.jretai.2006.08.005

Aziri B. (2011). Job satisfaction: a literature review. Management Research and Practice, 3(4), 77-86

Baba, VV \& Jamal, M. (1991). Routinisation of job context and job content as related to employees' quality of working life: a study of psychiatric nurses. Journal of Organisational Behaviour, 12, 379-386.https://doi.org/10.1002/job.4030120503

Babakus E \& Boller G. (1992). An empirical assessment of the Servqual Scale. Journal of Business Research, 24, 253-268 https://doi.org/10.1016/0148-2963(92)90022-4

Bagozzi, R.P \& Yi, Y (1988). On the evaluation of structural equation models. Journal of the Academy of Marketing Science, 16(1), 74-94. https://doi.org/10.1007/BF02723327

Bagozzi, R.P., Yi, Y \& Phillips, L.W. (1991). Assessing Construct Validity in Organizational Research. Adminstrative Science Quarterly, 36(3), 421-58. https://doi.org/10.2307/2393203 
Bahia K \& Nantel J. (2000). A reliable \& valid measurement scale for the perceived quality of banks. International Journal of Bank Marketing, 18(2), 84-91 https://doi.org/10.1108/02652320010322994

Bajpai N \& Srivastava D. (2011). Sectorial Comparison of Factors Influencing Job Satisfaction in Indian Banking Sector. Singapore Management Review, 26(2), 89-99.

Balogun A \& Olowodunoye S. (2012). Psychological factors as predictors of turnover intention among employees of post-consolidation banks in Nigeria. European Scientific Journal, 8(20), 81-95.

Baron RM \& Kenny D. (1986). The moderator-mediator distinction in social psychological research: Conceptual, strategic, \& statistical considerations. Journal of Personality \& Social Psychology, 51,1173-1182. https://doi.org/10.1037//0022-3514.51.6.1173

Baron RM \& Kenny DA. (1986). The moderator-mediator variable distinction in social psychological research, conceptual, strategic \& statistical considerations. Journal of Personality \& Social Psychology, (55), 1173-1182 https://doi.org/10.1037//0022-3514.51.6.1173

Bashir M, Ghazanfar F \& Mahroof Khan M. (2011). Role of Demographic Factors in the Relationship between High Performance Work System \& Job Satisfaction: A Multidimensional Approach. International Journal of Business \& Social Science, 2(18), 207-218

Becker G S. (1964). Human capital. New York: Columbia University Press

Bedeian A, Ferris G \& Kacmar M. (1992). Age, Tenure, \& Job Satisfaction: A Tale of Two Perspectives. Journal of Vocational Behavior, 40(1992), 33-48 https://doi.org/10.1016/0001-8791(92)90045-2

Bedeian A, Ferris GR \& Kacmar KM. (1992). Age tenure, \& job satisfaction: A tale of two perspectives. Journal of Vocational Behavior, 40(1), 33-48 https://doi.org/10.1016/0001-8791(92)90045-2

Bender K \& Heywood J. (2006). job satisfaction of the highly educated: the role of gender, academic tenure, \& earnings. Scottish Journal of Political Economy, 53(2), 253-279. https://doi.org/10.1111/j.1467-9485.2006.00379.x

Bender K \& Roche K. (2013). Educational Mismatch \& Self-Employment Forthcoming. Economics of Education Review, 2013 https://doi.org/10.1016/j.econedurev.2013.01.010

Benoit D \& Dirk Van den Poel. (2012). Improving customer retention in financial services using kinship network information. Expert Systems with Applications, $39(2012), \quad$ 11435-11442 https://doi.org/10.1016/j.eswa.2012.04.016

Bernhardt K, Donthu N \& Kennett P. (2000). A Longitudinal Analysis of Satisfaction \& Profitability. Journal of Business Research, 47(2000), 161-171 https://doi.org/10.1016/S0148-2963(98)00042-3

Berry L. (1995). Relationship Marketing of Services-Growing Interest, Emerging Perspectives. Journal of the Academy of Marketing Science, 23(4), 236-245. https://doi.org/10.1177/009207039502300402

Berry L. (1881). The employee as customers. Journal of Retail Banking, 3(March), 25-28

Berry LL \& Parasuraman A. (1991). Marketing Services, Competing Through Quality. Free Press : New York.

Bettencourt L \& Brown S. (1997). Contact Employees: Relationships Among Workplace Fairness, Job Satisfaction \& Pro social Service Behaviors. Journal of Retailing, 73(1), 39-61 https://doi.org/10.1016/S0022-4359(97)90014-2

Bick G, Abratt R. \& Möller D. (2010). Customer service expectations in retail banking in Africa. S. Afr. J. Bus. Manage, 4l(2), 13-27 https://doi.org/10.4102/sajbm.v41i2.515

Bigliardi B, Dormio A, Galati F \& Schiuma G. (2012). The impact of organizational culture on the job satisfaction of knowledge workers. VINE: The journal of information \& knowledge management systems, 42(1), 36-51 https://doi.org/10.1108/03055721211207752

Black S \& Sherwood G. (2010). Developing a valid \& reliable measurement of attitudes toward salespeople. Journal of Selling \& Major Account Management, 10(2), 27-39

Booth, Alison L. \& Marco Francesconi. (1990). Job Mobility in 1990s Britain: Does Gender Matter? Mimeo,1999.

Borkowski N, Amann R, Seok-Ho Song \& Weiss C. (2007). Nurses' intent to leave the profession: Issues related to gender, ethnicity, \& educational level. Health Care Manage Rev, 2007, 32(2), 160-167 https://doi.org/10.1097/01.HMR.0000267793.47803.41

Boselie P, Paauwe J \& Richardson R. (2003). Human resource management, institutionalization \& organizational 
performance: a comparison of hospitals, hotels \& local government. The International Journal of Human Resource Management, 14(8), 1407-1429. https://doi.org/10.1080/0958519032000145828

Bounfour A. (1999). Is outsourcing of intangibles a real source of competitive advantage? International Journal of Applied Quality Management, 2(2), 127-151https://doi.org/10.1016/S1096-4738(99)80087-6

Boyle M.E. (2001). The New Schoolhouse: Literacy, Managers, \& Belief. (Westport, CT: Praeger Publish-ers).

Brown S \& Lam S. (2008). A Meta-Analysis of Relationships Linking Employee Satisfaction to Customer Responses. Journal of Retailing, 84(3), 243-255 https://doi.org/10.1016/j.jretai.2008.06.001

Brown T. (2006). Confirmatory factor analysis for applied research. New York, London : the Guilford Press.

Buckinx W \& Dirk Van den Poel. (2005). Customer base analysis: partial defection of behaviourally loyal clients in a non-contractual FMCG retail setting. European Journal of Operational Research, 164(2005), 252-268https://doi.org/10.1016/j.ejor.2003.12.010

Bearfield, S. (2003). Quality of Working Life. ACIIRT Working paper 86. University of Sydney. www.acirrt.com.

Budhwar P, Varma A \& Malhotra N. (2009). Insights into the Indian call centre industry: can internal marketing help tackle high employee turnover. Journal of Services Marketing, 23(5), 351-362 https://doi.org/10.1108/08876040910973459

Byrne. (2009). Structural Equation Modeling With AMOS: Basic Concepts, Applications, \& Programming. 2nd Edition : Taylor \& Francis

Cadotte, Ernest R, Robert B. Woodruff \& Roger L. Jenkins. (1987). Expectations \& Norms in Models of Consumer Satisfaction. Journal of Marketing Research, 24(August), 305-314. https://doi.org/10.1177/002224378702400307

Campbell DJ \& Campbell KM. (2003). Global versus facet predictors of intention to quit: Differences in a sample of male \& female Singaporean managers \& non managers. The International Journal of Human Resource Management, 14(7), 1152-1177. https://doi.org/10.1080/0958519032000114246

Carricano, Poujol \& Bertr\&ias. (2011). Analyse des données avec SPSS. Paris : Pearson Education France, Collection Synthex.

Chan Yin-Fah B, Yeoh Sok Foon \& Lim Chee-Leong. (2010). An Exploratory Study on Turnover Intention among private Sector Employees. International Journal of Business \& Management, 5(8), 57-64. https://doi.org/10.5539/ijbm.v5n8p57

Ch\&ni Ohri. Reinventing financial services to the poorr - CEO, Grameen Foundation India Chang CS \& Chang HC (2009). Perceptions of internal marketing \& organizational commitment by nurses. Journal of Advanced Nursing, 65(1), 92-100 https://doi.org/10.1111/j.1365-2648.2008.04844.x

Chang P \& Chen W. (2002). The effect of Human Resource Management practices of firm performance : Empirical evidence from High-tech Firms in Taiwan. International Journal of Management, 19(4), 622-631

Chau PYK. (1997). Reexamining a model for evaluating information center success using a structural equation modeling approach. Decision Sciences, 28(2), 309-334.https://doi.org/10.1111/j.1540-5915.1997.tb01313.x

Chauvet. (2003). Construction d'une échelle de mesure de la capacité, XIIème Conférence de l'Association Internationale de Management Stratégique ? Les Côtes de Carthage - 3, 4, 5 \& 6 Juin 2003

Chen Chia-Shang. (1985). Personality Traits, Growth Needs, Role Pressures, Job Satisfaction \& Turnover intention, Graduate Institute of Business Administration, Chung Yuan Christian University, Taiwan

Cheng-Ping Chang \& Wei-Chen Chang. (2008). Internal Marketing Practices \& Employees' Turnover Intentions in Tourism \& Leisure Hotels. The Journal of Human Resource \& Adult Learning, 4(2), 161-172

Chigozirim Peters Silvia Elham Mazdarani. (2008). The Impact of Employee Empowerment on Service Quality \& Customer Satisfaction in Service Organizations. Bachelor Thesis in Business Administration. Department: School of Sustainable, Develop ment of Society \& Technology. Malardalen University, Vasteras.

Christou E. (2010). Relationship marketing practices for retention of corporate customers in hospitality contract catering. Tourism \& Hospitality Management, 16(1), 1-10

Churchill. (1979). Paradigm for Developing Better Measures of Marketing Constructs. Journal of Marketing Research, 16(1), 64-73 https://doi.org/10.1177/002224377901600110 
Churchill G.A. \& Surprenant C. (1982). An investigation into the determinants of customer satisfaction. Journal of Marketing Research, 19(4), 491-504. https://doi.org/10.1177/002224378201900410

Clark M. (2002). The relationship between employees' perceptions of organizational climate \& customer retention rates in a major UK retail bank. Journal of Strategic Marketing, 10(2002), 93-113 https://doi.org/10.1080/09652540210125260

Clark-Rayner P. \& Harcourt M. (2000). The Determinants of Employee Turnover Behaviour: New Evidence from a New Zeal\& Bank. Research \& Practice in Human Resource Management, 8(2). 61-71.

Clemes M, Gan C \& Li Yan Zheng. (2007). Customer switching behavior in the New Zeal\& banking industry. Banks \& Bank Systems, 2(4), 50- 65

Coelho F, Augusto M \& Lages L. (2011). Contextual Factors \& the Creativity of Frontline Employees: The Mediating Effects of Role Stress \& Intrinsic Motivation. Journal of Retailing, 87(1), 31-45 https://doi.org/10.1016/j.jretai.2010.11.004

Cossette M \& Gosselin A. (2012). Quitter, rester ou progresser? Les profils d'intentions des agents en centre d'appels. Relations industrielles / Industrial relations, 67(4), 703-725 https://doi.org/10.7202/1013201 ar

Crié. (1996). Rétention de clientèle \& Fidélité des clients. Décisions Marketing, (7), (Janvier- Avril 1996), 25-30

Cronin J \& Talyor S. (1994). SERVPERF versus SERVQUAL : Reconciling Performance-based \& Perceptions-Minus-Expectations Measurement of Service Quality. Journal of Marketing, (58), 125-131. https://doi.org/10.1177/002224299405800110

Danna, K. \& Griffin, R. W. (1999). Health \& well-being in the workplace: A review \& synthesis of the literature. Journal of Management, 25, 357-384.https://doi.org/10.1177/014920639902500305

Davidson R \& MacKinnon JG. (1993). Estimation \& inference in econometrics. Oxford University Press: New York, NY

Drexler A \& Schoar A. (2014). Do Relationships Matter? Evidence from Loan Officer Turnover. Management Science (August 2014). https://doi.org/10.1287/mnsc.2014.1957

Duranta H. (2013). Relationship Between The Borrowers \& The Employees Of GrameenBank, Internship Report On Relationship Between The Borrowers \& The Employees Of Grameen Bank, BRAC Business School.

EnziC hang. (1999). Career Commitment as a Complex Moderator of Organizational. Commitment \& Turnover Intention, 52(10), https://doi.org/10.1177/001872679905201002

International Strategic Management Conference. Procedia - Social \& Behavioral Sciences, 99(2013), 665-672

Ellis N \& Pompli A. (2002). Quality of working life for nurses. Commonwealth Dept of Health \& Ageing. Canberra.

Evanschitzky H, Wangenheim F \& Wünderlich N. (2012). Perils of Managing the Service Profit Chain: The Role of Time Lags \& Feedback Loops. Journal of Retailing, 88(3), 356-366 https://doi.org/10.1016/j.jretai.2012.01.003

Easton, S. \& Van Laar, D. (2013). User Manual for the Work-Related Quality of Life (WRQoL) Scale. University of Portsmouth. UK.

Edwards, J., Van Laar, D.L. \& Easton, S. (2009). The Work-Related Quality of Life (WRQoL) scale for Higher Education Employees. Quality in Higher 207-219.https://doi.org/10.1080/13538320903343057

Ferguson K \& Reio T. (2010). Human resource management systems \& firm performance. Journal of Management Development, 29(5), 471-494 https://doi.org/10.1108/02621711011039231

Fornel, Michael D. Johnson, Eugene W., erson, Jaesung Cha, \& Barbara Everitt Bryant. (1996). The American Customer Satisfaction Index: Nature, Purpose, \& Findings. Journal of Marketing, 60(October), 7-18.https://doi.org/10.1177/002224299606000403

Fornell, C \& Larcker, D.F. (1981). Evaluating structural equation models with unobservable variables \& measurement error. Journal of Marketing Research, 18(1), 39-50. https://doi.org/10.1177/002224378101800104

Fornell, C. (1992). A National Customer Satisfaction Barometer : The Swedish Experience. Journal of Marketing, 56(January), 6-21. https://doi.org/10.1177/002224299205600103

Gelade G \& Ivery M. (2003). The Impact of Human Resource Management \& Work Climate on Organizational Performance. Personnel Psychology, (56), 383-404 https://doi.org/10.1111/j.1744-6570.2003.tb00155.x 
Gelade G \& Young S. (2005). Test of a service profit chain model in the retail banking sector. Journal of Occupational \& Organizational Psychology, 78(2005), 1-22 https://doi.org/10.1348/096317904X22926

George W.R. (1977). The retailing of services a challenging future. Journal of Retailing, Fall, 85-98.

George J \& Jones G. (1996). The Experience of Work \& Turnover Intentions: Interactive Effects of Value Attainment, Job Satisfaction, \& Positive Mood. Journal of Applied Psychology, 81(3), 318-325 https://doi.org/10.1037//0021-9010.81.3.318

George W. (1990). Internal Marketing : concepts, measurement \& application. Journal of Retailing, 35(3), 85-98

Gilleya M, Greerb C \& Rasheed A. (2004). Human resource outsourcing \& organizational performance in manufacturing firms. Journal of Business Research, 57(2004), 232- 240 https://doi.org/10.1016/S0148-2963(02)00304-1

Goetz A M. (1996). Local Heroes Patterns of Field Worker Discretion in Implementing GAD Policy in Bangladesh' IDS, Discussion paper 358

Gong Y, Law K \& Chang S. (2009). Human Resources Management \& Firm Performance: The Differential Role of Managerial Affective \& Continuance Commitment. Journal of Applied Psychology, 94(1), 263-275 https://doi.org/10.1037/a0013116

Gouldner A W. (1960). The norm of reciprocity. American Sociological Review, 25, 165-167 https://doi.org/10.2307/2092623

Gounaris S. (2006). The notion of internal market orientation \& employee job satisfaction: some preliminary evidence. Journal of services Marketing, 21(1), 68-90 https://doi.org/10.1108/08876040810851978

Gounaris S. (2008). Antecedents of internal marketing practice: some preliminary empirical evidence. International Journal of Service Industry Management, 19(3), 400-434 https://doi.org/10.1108/09564230810875039

Greenberg J. (1990). Employee Theft as a Reaction to Underpayment Inequity: The Hidden Cost of Pay Cuts. Journal of Applied Psychology, 75(5), 561-568 https://doi.org/10.1037//0021-9010.75.5.561

Gremler D \& Gwinner K. (2008). Rapport-Building Behaviors Used by Retail Employees. Journal of Retailing, 84(3, 2008), 308-324 https://doi.org/10.1016/j.jretai.2008.07.001

Gremler, D., Bitner, M.J. \& Evans, K. (1994). The internal service encounter. International Journal of Service Industry Management, 5(2), 34-56. https://doi.org/10.1108/09564239410057672

Griffeth R, Hom P \& Gaertner S. (2000). A Meta-Analysis of Antecedents \& Correlates of Employee Turnover : Update, Moderator Tests, \& Research Implications for the Next Millennium. Journal of Management, 26(3), 463-48 https://doi.org/10.1016/S0149-2063(00)00043-X

Grönroos. (1993). Toward a Third phase in service quality research : challenges \& Future directions, Advances in Services Marketing \& Management, 2, 49-64

Gronroos C. (1985). Internal marketing - theory \& practice. In: Bloch TM, Upah GD,

Grunert K, Dean M \& Raats M. (2007). A measure of satisfaction with food-related life. Appetite, 49(2007), 486-493 https://doi.org/10.1016/j.appet.2007.03.010

Guest D. (1997). Human resource management \& performance: a review \& research agenda. The International Journal of Human Resource Management, 8(3), June 1997 https://doi.org/10.1080/095851997341630

Gul G, Bashir M \& Lal Rohra C. (2011). Qualitative Study thn Customer Attrition in Guo L, Hair, Black, Babin (2010). Multivariate Data analysis : Pearson Prentice Hall . 7 Edition.

Halstead D, David H \& Schmidt S. (1994). Multisource Effects on the Satisfaction Formation Process. Journal of the Academy of Marketing Science, 22(Spring), 114-129. https://doi.org/10.1177/0092070394222002

Hanisch K \& Hulin C. (1991). General Attitudes \& Organizational Withdrawal: An Evaluation of a Causal Model. Journal of Vocational Behavior, 39(1991), 110-128https://doi.org/10.1016/0001-8791(91)90006-8

Harel G \& Tzafrir S. (1999). the effect of human resource management practices on the perceptions of organizational \& Market Performance of the Firm. Human Resource Management, 38(3), 185-200 https://doi.org/10.1002/(SICI)1099-050X(199923)38:3\%3C185::AID-HRM2\%3E3.0.CO;2-Y

Harrison-Walker L. (2000). Service Quality in the Hair Salon Industry. Journal of Business isciplines, XI(2000). $1527-151 X$ 
Hart L, Lopez J \& Jalbert M. (2007). Are retail banks satisfying their customers in Costa Rica? Global Journal of Business Research, 1(2), 73- 86

Harter J, Schmidt F \& Hayes T. (2002). Business-Unit-Level Relationship Between Employee Satisfaction, Employee Engagement, \& Business Outcomes: A Meta-Analysis. Journal of Applied Psychology, 87(2), 268-279 https://doi.org/10.1037//0021-9010.87.2.268

Hartog D, Boon C \& Verburg R. (2013). HRM, Communication, Satisfaction, \& Perceived Performance: A Cross-Level Test. Journal of Management, 3(6), 1637-1665 https://doi.org/10.1177/0149206312440118

Harvey P, Harris K \& Martinko M. (2008). The Mediated Influence of Hostile Attributional Style on Turnover Intentions. J Bus Psychol, 22(2008), 333-343 https://doi.org/10.1007/s10869-008-9073-1

Hatfield E, Cacioppo J.T \& Rapson, R.L. (1994). Emotional Contagion. Cambridge University Press: Cambridge, Engl.https://doi.org/10.1017/CBO9781139174138

Hatfield, E, Cacioppo JT \& Rapson RL. (1992). Emotional Contagion. eds. Review of Personality \& Social Psychology. CA, Newbury Park, 151-177. https://doi.org/10.1017/CBO9781139174138

Haverila M. (2011). Mobile phone feature preferences, customer satisfaction \& repurchase intent among male users. Australasian Marketing Journal, 19(2011), 238-246 https://doi.org/10.1016/j.ausmj.2011.05.009

Hellman C. (1997). Job Satisfaction \& Intent to Leave. The Journal of Social Psychology, 137(6), 677-689 https://doi.org/10.1080/00224549709595491

Hellriegel D \& Slocum JW. (2004). Organizational behavior, Thomson, South-Western.

Hennig-Thurau T \& Klee A. (1997). The Impact of Customer Satisfaction \& Relationship Quality on Customer Retention: A Critical Reassessment \& Model Development. Psychology \& Marketing, 14(8),737-764 https://doi.org/10.1002/(SICI)1520-6793(199712)14:8\%3C737::AID-MAR2\%3E3.3.CO;2-Z

Heriyati P \& Ramadhan a. (2012). The Influence of Employee Satisfaction in Supporting Employee Work Performance \& Retention Moderated by the Employee Engagement Factor of an Institution (An Empirical Study of Binus Business School). Int. Journal of Economics \& Management, 6(1), 191 - 200

Herzberg F, Mausner B, Peterson R \& Capwell D. (1957). Job attitudes: Review of research \& opinion. Pittsburgh, PA: Psychological Service of Pittsburgh.

Herzberg F, Mausser B \& Snyderman. (1959). The motivation to work. Transaction Publishers: New Brunswick(U.S.A.) \& London(U.K.)

Huselid M. (1995). The Impact of Human Resource Management Practices on Turnover, Productivity, \& Corporate Financial Performance. The Academy of Management Journal, 38(3), 635-672

Hoppock, R \& Spiegler, S. (1935). Job Satisfaction, Researches of 1935-1937, First published: April 1938, https://doi.org/10.1002/j.2164-5892.1938.tb00348.x

Huselid M, Jackson S \& R\&all S. (1997). Technical \& Strategic Human Resource Management Effectiveness as Determinants of Firm Performance. The Academy of Management Journal, 40(1), 171-188 https://doi.org/10.2307/257025

Hwang I \& Chi G. (2005). Relationships among Internal Marketing, Employee Job Satisfaction \& International Hotel Performance: An Empirical Study. International Journal of Management, 22(2), 285-293

Igalens J. (1999). Satisfaction au travail in Encyclopédie de la gestion \& du management Inmyxai S, Takahashi Y \& Higashi-Hiroshima (2010). Performance Contrast \& Its Determinants between Male \& Female Headed Firms in Lao MSMEs. International Journal of Business \& Management, 5(4), https://doi.org/10.5539/ijbm.v5n4p37

Jang J \& George R. (2012). Underst\&ing the influence of polychronicity on job satisfaction \& turnover intention: A study of non-supervisory hotel employees. International Journal of Hospitality Management, 31(2012), 588- 595 https://doi.org/10.1016/j.ijhm.2011.08.004

Jaramillo F, Grisaffe D \& Chonko L. (2009). examining the impact of servant leadership on salesperson's turnover intention. Journal of Personal Selling \& Sales Management, XXIX(4), 351-365.https://doi.org/10.2753/PSS0885-3134290404

Jeon H \& Choi B. (2012). The relationship between employee satisfaction \& customer satisfaction. Journal of Services Marketing, 26(5), 332-341 https://doi.org/10.1108/08876041211245236 
JoBitner M,Booms B \& Mohr L. (1994). Critical Service Encounters : The Employee's View point. Journal of Marketing, 58(October1994), 95-10 https://doi.org/10.2307/1251919

Johnson J. (1996). Linking employee perceptions of service climate to customer satisfaction. Personnel Psychology, 49(4), 831-851 https://doi.org/10.1111/j.1744-6570.1996.tb02451.x

Johnson S. (2008). second that emotion: Effects of emotional contagion \& affect at work on leader \& follower outcomes. The Leadership Quarterly, 19(2008), 1-19 https://doi.org/10.1016/j.leaqua.2007.12.001

Jung H \& Yoon H. (2013). Do employees' satisfied customers respond with a satisfactory relationship? The effects of employees' satisfaction on customers' satisfaction \& loyalty in a family restaurant. International Journal of Hospitality Management, 34(2013), 1- 8 https://doi.org/10.1016/j.ijhm.2013.02.003

Khanchel, Hanen \& Ben Kahla, Karim. (2018). Gender-Role Stereotypes: Perception of Tunisian Leaders, 7(4), 2018https://doi.org/10.5430/bmr.v7n4p22

Khanchel, Hanen \& Ben Kahla, Karim. (2018). Intercultural Management between Tunisia \& Europe. Journal of Business Administration Research, 7(2), 2018https://doi.org/10.5430/jbar.v7n2p40

Kabungaidze T, Mahlatshana N \& Ngir\&e H. (2013). The Impact of Job Satisfaction \& Some Demographic Variables on Employee Turnover Intentions. International Journal of Business Administration, 4(1), 53-65https://doi.org/10.5430/ijba.v4n1p53

Lawler III E \& Porter L. (1966). Managers' pay \& their satisfaction with their pay. Personnel Psychology, XIX, 363-73.https://doi.org/10.1111/j.1744-6570.1966.tb00311.x

Lawler, E. E. (1982). Strategies for improving the quality of work life. American Psychologist, 37, 2005, 486-493.https://doi.org/10.1037/0003-066X.37.5.486

Loscocco, K. A. \& Roschelle, A. N. (1991). Influences on the Quality of Work \& Nonwork Life: Two Decades in Review. Journal of Vocational Behavior, 39, 182-225.https://doi.org/10.1016/0001-8791(91)90009-B

Murrar Abdullah \& Hamad, Afif. (2013). Relationship between Job Satisfaction \& Turnover Intension: An Empirical Study on the IT Firms in Palestine. Interdisciplinary Journal of Research in Business, 2(8), 67- 83 2013, ISSN: 2046-7141

Mirvis, P.H. \& Lawler, E.E. (1984). Accounting for the Quality of Work Life. Journal of Occupational Behaviour, 5, 197-212.https://doi.org/10.1002/job.4030050304

Sahnoun Marwa \& Abdennadher Chokri. (2019). The nexus between unemployment rate \& shadow economy: a comparative analysis of developed $\&$ developing countries using a simultaneous-equation model, Economics.

Sharma E \& Mani M. (2012). A Comparative Analysis of Employee Satisfaction in Indian Commercial Banks. The IUP Journal of Organizational Behavior, XI(4), 38-61

Sharma J. (2012). Impact of Market Orientation on Business Performance: Role of Employee job satisfaction \& Customer Satisfaction. Vision, 16(4), 297-313 https://doi.org/10.1177/0972262912460188

Sharma, S. (1996). Applied Multivariate Techniques. Johnson Wiley \& Sons.

Siddiqi O. (2011). Interrelations between Service Quality Attributes, Customer Satisfaction \& Customer Loyalty in the Retail Banking Sector in Bangladesh. International Journal of Business \& Management, 6(3), 12-36 https://doi.org/10.5539/ijbm.v6n3p12

Siders, M. A., George, G \& Dharwadkar, R. (2001). The relationship of internal \& external commitment foci to objective job performance Measures. Academy of Management Journal, 44, 570-579. https://doi.org/10.2307/3069371

Silvestro, R \& Cross S. (2000). Applying the service profit chain in a retail environment. International Journal of Service Industry Management, 11(3), 244-268. https://doi.org/10.1108/09564230010340760

Simanowitz A (nd). Challenges to the Field \& Solutions: Over-Indebtedness, Client Drop-Outs, Unethical Collection Practices, Exorbitant Interest Rates, Mission Drift, Poor Governance Structures \& More.

Singh. (1991). Underst\&ing the structure of consumers satisfaction evaluations of service delivery. Journal of the Academy of Marketing Science, 19(3), 223-244 https://doi.org/10.1177/009207039101900307

Singh P \& Loncar N. (2010). Pay Satisfaction. Job Satisfaction \& Turnover Intent, relations industrielles / industrial relations, 65(3), 470 - 490 https://doi.org/10.7202/044892ar 
Singh R \& Koshy A. (2011). Does salesperson's customer orientation create value in B2B relationships? Empirical evidence from India. Industrial Marketing Management, 40(2011), 78-85 https://doi.org/10.1016/j.indmarman.2010.09.012

Smith, P.C., Kendall, L.M \& Hulin, C.L. (1969). The Measurement of Satisfaction in Work \& Retirement. R\&-McNally, Chicago.

Sirgy, M. J., Efraty,, D., Siegel, P \& Lee, D. (2001). A new measure of quality of work life (QoWL) based on need satisfaction \& spillover theories. Social 241-302.https://doi.org/10.1023/A:1010986923468

Indicators Research,

55,

Sousa-Poza A \& Sousa-Poza AA. (2000). Well-being at work: a cross-national analysis of the levels \& determinants of job satisfaction. The journal of socio-economics, 29(6), 517-538https://doi.org/10.1016/S1053-5357(00)00085-8

T S Nanjundeswaraswamy \& Swamy D R. (2013). Quality of worklife of employees in private technical institutions. International Journal for Quality Research, 7(3), 3-14, ISSN 1800-6450.

Thompson, E.R \& Phua, F.T.T. (2012). A Brief Index of Affective Job Satisfaction. Group \& Organization Management, 37(3), 275-307, https://doi.org/10.1177/1059601111434201

Van Laar, D, Edwards, J \& Easton, S. (2007). The Work-Related Quality of Life scale for healthcare workers. Journal of Advanced Nursing, 60(3), 325-333.https://doi.org/10.1111/j.1365-2648.2007.04409.x

Wagner L \& Hollenbeck C. (2005). Organizational Behavior: Securing Competitive Advantage. 5th Edition, Thomson South-Western, NY.

Wallace E, Chernatony L \& Buil I. (2013). Building bank br\&s: How leadership behavior influences employee commitment. Journal of Business Research, 66(2013), 165-171 https://doi.org/10.1016/j.jbusres.2012.07.009

Wang G, Yu-Je Lee \& Chuan-Chih Ho. (2012). The Effects of Job Satisfaction, Organizational Commitment \& Turnover intention on Organizational operating performance: as Exemplified with Employees of Listed Property Insurance Companies in Taiwan. Research in Business \& Management, 1(2), 41-53.

Wangenheim F, Evanschitzky H \& Wunderlich M. (2007). Does the employee-customer satisfaction link hold for all employee groups? Journal of Business Research, 60(2007), 690-697 https://doi.org/10.1016/j.jbusres.2007.02.019

Waterfield C. (2006). Putting Client Assessment to Work, Technical Note \#2 : The Challenges of Measuring Client Retention,ThePractitioner Learning Program, Copyright (C) 2006 The SEEP Network

Wayne SJ, Shore LM \& Liden RC. (1997). Perceived organizational support \& leader-member exchange: a social exchange perspective. Academy Management Journal, 40(1),82-111. https://doi.org/10.2307/257021

Wei (Amy) Tian-Foreman. (2009). Job satisfaction \& turnover in the Chinese retail industry. Chinese Management Studies, 3(4), 356-378 https://doi.org/10.1108/17506140911007503 